UCRL-JC- 123971

PREPRINT

CONF.960401- 52

\title{
GRAPHITIZED NEEDLE COKES AND NATURAL GRAPHITES FOR LITHIUM INTERCALATION
}

\author{
T.D. Tran
}

L. M. Spellman

R. W. Pekala

W. M. Goldberger

K. Kinoshita

This paper was prepared for submittal to the

Microporous and Macroporous Materials Symposium of the Spring Meeting of the Materials Research Society

San Francisco, California

April 8-12, 1996

May 10, 1996

This is a preprint of a paper intended for publication in a journal or proceedings. Since changes may be made before publication, this preprint is made available with the understanding that it will not be cited or reproduced without the permission of the author. 
DISCLAIMER

This document was prepared as an account of work sponsored by an agency of the United States Government. Neither the United States Government nor the University of California nor any of their employees, makes any warranty, express or implied, or assumes any legal liability or responsibility for the accuracy, completeness, or usefulness of any information, apparatus, product, or process disclosed, or represents that its use would not infringe privately owned rights. Reference herein to any specific commercial product, process, or service by trade name, trademark, manufacturer, or otherwise, does not necessarily constitute or imply its endorsement, recommendation, or favoring by the United States Government or the University of California. The views and opinions of authors expressed herein do not necessarily state or reflect those of the United States Government or the University of California, and shall not be used for advertising or product endorsement purposes. 


\section{GRAPHITIZED NEEDLE COKES AND NATURAL GRAPHITES FOR LITHIUM INTERCALATION}

T. D. TRAN*, L. M. SPELLMAN*, R. W. PEKALA*, W. M. GOLDBERGER $†$ and K. KINOSHITA $\ddagger$ *Chemistry \& Materials Science Department,

Lawrence Livermore National Laboratory, Livermore, CA 94550

$\dagger$ Superior Graphite Co., Chicago, IL 60606

$\$$ Energy and Environment Division,

Lawrence Berkeley National Laboratory, Berkeley, CA 94720

\section{INTRODUCTION}

The microstructure of carbonaceous materials strongly affect their ability to electrochemically intercalate lithium [1]. The fractional intercalation capacity ( $\mathrm{x}$ in $\mathrm{Li}_{\mathrm{x}} \mathrm{C}_{6}$ ) for various types of amorphous and graphitic carbons can vary over a range between 0 to 1 . Capacities exceeding that of graphite $\left(372 \mathrm{mAh} / \mathrm{g}\right.$ or $\left.\mathrm{LiC}_{6}\right)$ can be obtained from chemically doped (i.e., with phosphorous [2]) materials or from carbonized organic precursors pyrolyzed at low temperatures $\left(<900^{\circ} \mathrm{C}\right)$ [3]. Additional chemical effects apparently influence the carbon electrochemical behavior in these cases.

For a certain group of pure but graphitizable cokes and carbons, the heat-treatment temperature can cause changes in the particle structure and morphology resulting in a significant variation in the electrochemical performance. Several groups $[1,4]$ have demonstrated that the structure of heat-treated carbons changes over a broad range of temperature $\left(1200-2800^{\circ} \mathrm{C}\right)$. The lithium storage capacity usually goes through a minimum and then increases with increasing graphitization temperature up to that of graphite $\left(\mathrm{LiC}_{6}\right)$. We have previously reported [5] a significant reduction $(50 \%)$ in the performance of a carbon black (Sterling $\mathrm{R}$, Cabot) that was heat treated to $2700^{\circ} \mathrm{C}$. On the basis of transmission electron microscopy analysis, it was thought that the graphitized, onion-skin type structural orientation could limit accessibility in the internal crystallites resulting in a reduced overall capacity. A more open graphitic structure (e.g., edgeoriented surface) would perhaps be more desirable for efficient insertion/de-insertion reactions.

Processing conditions such as milling (grinding) to pulverize the coarser particles can alter the particle surface morphology. Tatsumi and co-workers [6], for example, observed that fibers that were chopped after graphitization treatment showed a significant improvement in capacity ( 1.6 times) over those that were chopped prior to graphitization. In this work, we are examining the effects of both heat treatment and milling (either prior to or after the heat treatment) to examine the relative significance of these two parameters on the intercalating ability of needle petroleum coke. The performance of natural graphite particles which have similar physical properties is included for comparison.

\section{EXPERIMENTAL}

The coke material is a calcined coke (190LS, Superior Graphite Co.). This readily graphitizable coke is referred to as a needle petroleum coke and is used commercially to make large graphite electrodes. This particular coke material is low in sulfur $(<1 \%)$ and other elements $(0.05-0.15 \%)$. The cokes were processed according to the following procedures using identical time-temperature schedules: 1) The coarse grains ( $-3 / 8^{\prime \prime}$ mesh ROK) were heat treated and subsequently air milled to a fine powder (average particle size $\sim 10 \mu \mathrm{m}$ ); 2) The coarse materials were air milled prior to heat treatment. The graphitization experiments were done in a laboratory graphite resistance tube furnace at three temperatures 1800,2100 , and $2350^{\circ} \mathrm{C}$ in a flowing argon stream. A sample designation $1800 \mathrm{M}$ means that the coke was first treated to $1800^{\circ} \mathrm{C}$ before being milled $(M)$ to the final size. The electrodes were prepared using a commercial, $0.12-\mathrm{mm}$ thick carbon fiber sheet (Lydall Corp.) as the support matrix and a carbonized phenolic resin binder (10-15\%). A slurry containing the carbon particles, phenolic resin precursor (\#29-217, Reichhold Chemical) and furfuryl alcohol (QO Chemicals, Inc.) was spread onto the carbon fiber 
sheet and allowed to dry. The composites were then pyrolyzed at $1050^{\circ} \mathrm{C}$ (in $\mathrm{N}_{2}$ ). The final electrode thickness was between 0.26 and $0.30 \mathrm{~mm}$. Other details can be found elsewhere [5].

The electrochemical experiments were carried out in a $15-\mathrm{ml}$, three-electrode cylindrical cell. Lithium foils (Cyprus Foote Mineral) were used as the counter and reference electrodes. Fiberglass filters (Whatman 934-AH) were used as the separators between the working and counter electrodes. The electrolyte was $0.5 \mathrm{M}$ lithium (bis)trifluoromethanesulfonimide (HQ115, 3M Corp.) in 50:50 ethylene carbonate:dimethyl carbonate (Grant Chemical). The cells were constructed and tested at $20 \pm 2^{\circ} \mathrm{C}$ in a dry argon-atmosphere glove box $(<15 \mathrm{ppm}$ water). The electrode was discharged (intercalated) at a constant-current rate corresponding to 1 mole of lithium per 6 moles of carbon in 24 hours (ca. C/24 rate) to a cut-off voltage of $0.005 \mathrm{~V}\left(\mathrm{Li}^{+} / \mathrm{Li}\right)$ and held at this potential for 4 hours. It was then charged (deintercalated) at the same rate to 1.5 $\mathrm{V}$ and held there for another 4 hours. This procedure was used to ensure complete lithium intercalation/deintercalation. Electrochemical studies were performed using a 64-channel Maccor battery tester.

BET surface area measurements were obtained with a multi-point method using a Micromeritics ASAP 2000 Surface Area Analyzer. Particle size distribution was obtained from Micro-Tract analysis.

\section{-RESULTS AND DISCUSSION}

The physical properties and electrochemical intercalating parameters of the cokes and graphite are summarized in Table I. The particle size distributions on the two series of cokes milled before and after heat treatment are shown in Figures $1 \mathrm{a}$ and $1 \mathrm{~b}$, respectively. The curves show a distribution with an average particle size near $10 \mu \mathrm{m}$. A higher maximum was observed with the samples that are milled after heat treatment. Nitrogen gas adsorption analysis showed a clear difference in the BET surface areas of the two sets of materials. The surface areas of samples that are milled after heat treatment are approximately twice as large as those milled after heating (see Table I). Electron microscopy and X-ray diffraction analyses are underway to study any difference in their microstructure and surface morphology.

The potential profiles as a function of lithium intercalation capacity, $\mathrm{x}$ (in $\mathrm{Li}_{\mathrm{X}} \mathrm{C} 6$ ), for electrodes containing the coke powders milled prior to heat treatment are presented in Figure 2. The curves for samples that were heat treated before milling are shown in Figure 3 . Both discharge (intercalation) and charge (deintercalation) curves are presented on the same $\mathrm{x}$-axis for ease of observation and comparison. The profiles of samples heat treated at temperatures below $2100^{\circ} \mathrm{C}$ regardless of the milling order show a sloping curve over the capacity range characteristic of the behavior for amorphous carbons. Flat plateaus below $0.25 \mathrm{~V}$ start to develop for materials processed at higher temperatures, indicating the development of ordered graphene layers associated with the graphitic structure. The trend here is in agreement with those reported for pitch cokes $[1,4]$.

Table I. Physical properties and performance of treated coke powders and natural graphite

\begin{tabular}{|l|l|c|c|c|c|}
\hline Sample & Process conditions & $\begin{array}{c}\text { Particle size } \\
(\mu \mathrm{m})\end{array}$ & $\begin{array}{c}\text { BET area } \\
\left(\mathrm{m}^{2} / \mathrm{g}\right)\end{array}$ & $\begin{array}{c}\text { Capacity } \\
\left(\mathrm{x} \text { in Li } \mathrm{C}_{6}\right)\end{array}$ & $\begin{array}{c}\text { Irreversible } \\
\text { capacity } \\
(\mathrm{mAh} / \mathrm{g})\end{array}$ \\
\hline $\mathrm{SO} 22$ & control, as-received & $30-40$ & 0.4 & 0.69 & 65 \\
\hline $\mathrm{SO} 23$ & milling $+1800^{\circ} \mathrm{C}$ & 10 & 5.6 & 0.45 & 81 \\
\hline $\mathrm{SO} 24$ & milling $+2100^{\circ} \mathrm{C}$ & 10 & 4.6 & 0.74 & 110 \\
\hline $\mathrm{SO} 25$ & milling $+2350^{\circ} \mathrm{C}$ & 10 & 4.3 & 0.81 & 130 \\
\hline SO26 & $1800^{\circ} \mathrm{C}+$ milling & 10 & 9.3 & 0.56 & 72 \\
\hline SO27 & $2100^{\circ} \mathrm{C}+$ milling & 10 & 9.8 & 0.82 & 70 \\
\hline SO28 & $2350^{\circ} \mathrm{C}+$ milling & 10 & 9.2 & 0.93 & 69 \\
\hline BG74A & natural graphite & 10 & 10 & 0.92 & 94 \\
\hline
\end{tabular}



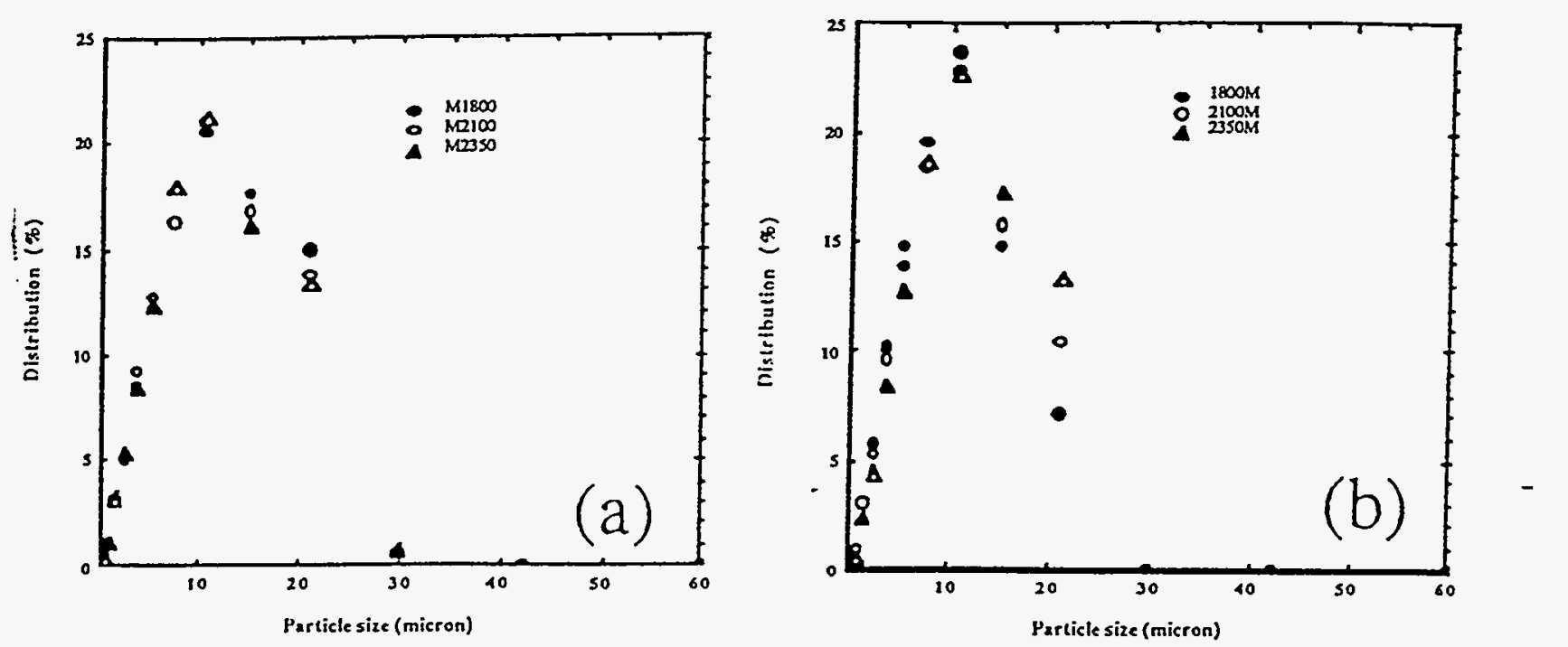

Figure 1. Particle size distribution of (a) samples that were milled first before heat treatment and (b) samples that were milled after heat treatment.

The lithium capacity is plotted as a function of heat treatment temperature in Figure 4. There appears to be a minimum in both curves for the two series. The lowest capacity $(x=0.45)$ occurs at $\sim 1800^{\circ} \mathrm{C}$. Additional data points are needed to clearly establish the minimum but the presence of one is evident. The series of electrodes made from materials milled after graphitization showed $15-20 \%$ higher capacities compared to those that were milled prior to heat treatment. Furthermore, the electrochemical behavior of sample $2350 \mathrm{M}$ is unusually similar to that observed for highly graphitic natural graphite (see Table I). Heat treatment conditions in-this case apparently are sufficient for the highly graphitic crystalline structure to form. The sample microstructure will be examined in more detail by electron microscopy and X-ray diffraction study. The irreversible capacity loss (Table I) associated with the formation of the solidelectrolyte interphase does not appear to correspond with the BET surface areas as might be expected from the study by Fong et al. [7]. We are not clear at this point about this relationship for these two series of heat-treated samples.

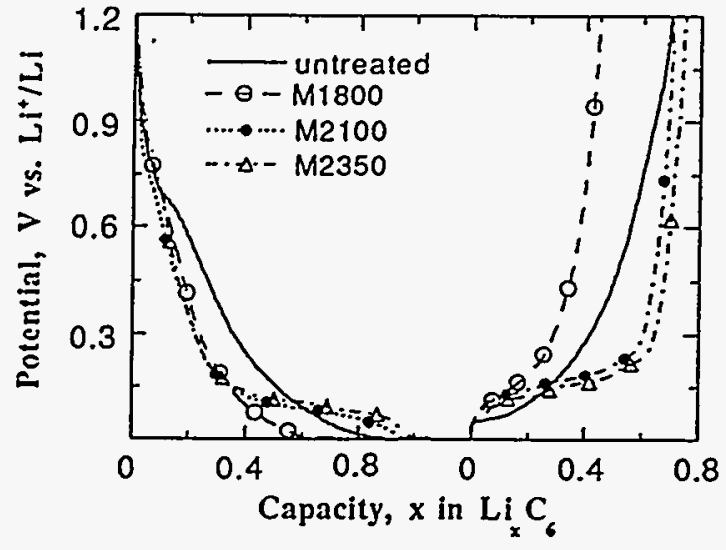

Figure 2. Plot of discharge and charge potentials as a function of capacities, $\mathrm{x}$ in $\mathrm{Li}_{x} \mathrm{C}_{6}$ for electrodes containing cokes particles that were milled to a powder then heat treated at 1800 , 2100 and $2350^{\circ} \mathrm{C}$.

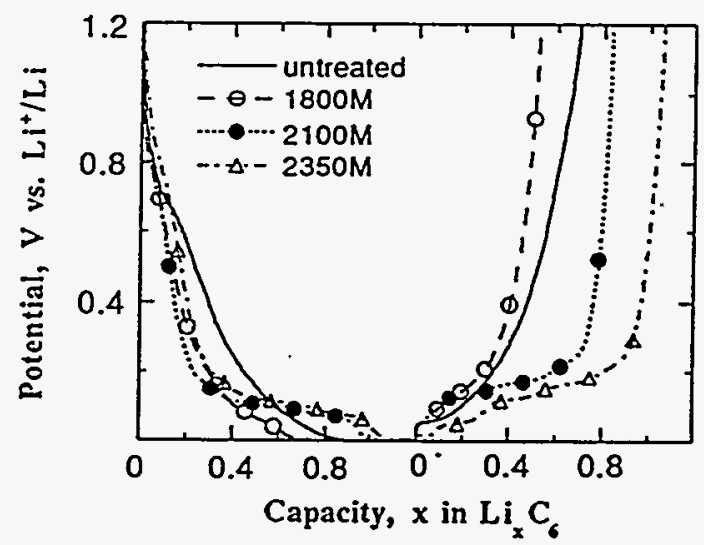

Figure 3. Plot of discharge and charge potentials as a function of capacities, $x$ in $\mathrm{Li}_{x} \mathrm{C}_{6}$ for electrodes containing coke particles that were heat treated at 1800,2100 and $2350^{\circ} \mathrm{C}$ before being milled to fine powders. 


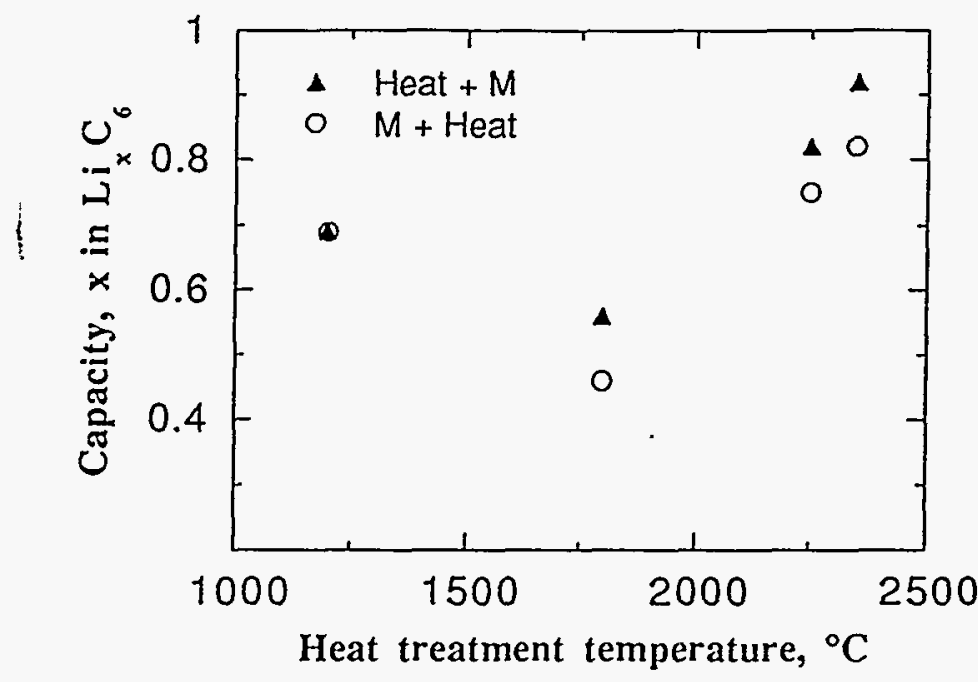

Figure 4. Plot of reversible capacities as a function of heattreatment temperatures. Electrolyte, $0.5 \mathrm{M} \quad \mathrm{LiN}\left(\mathrm{CF}_{3} \mathrm{SO}_{2}\right)_{2} / \quad 50: 50$ EC:DMC.

The milling process represents more than a three order-of-magnitude change in the particle dimensions on a volumetric basis. As expected the materials milled after graphitization $(1800 \mathrm{M}, 2100 \mathrm{M}$ and $2350 \mathrm{M})$ contain an open structure with a large fraction of active edgeoriented surfaces to more fully utilize the bulk structure for insertion. On the other hand, graphitization of the milled powders could close off certain crystallites in the bulk structure which would not be accessible for insertion even at a slow rate (eg., C/24).

Scanning and transmission electron microscopy experiments will allow more detailed examination of the particle microstructures. These preliminary results suggest that the change in the particle microstructure by milling is not a critical factor causing a decrease in capacity (i.e., the onset of a minimum in the $x$ vs. $L_{c}$ curve). The minimum capacity apparently is intrinsic to the carbon structure although a satisfactory explanation for its existence is not available at this time.

\section{ACKNOWLEDGMENT}

The authors thank Mr. Peter Zaleski and Mr. Dave Derwin (Superior Graphite Co.) for help with the preparation of the coke materials, and Ms. Suzanne Hulsey (LLNL) for BET surface area measurements. This work was performed under the auspices of the U. S. Department of Energy by the Lawrence Livermore National Laboratory under Contract No. W-7405-ENG-48 and Lawrence Berkeley National Laboratory under Contract No. DE-AC03-76SF00098. Financial support was received from the Assistant Secretary for Energy Efficiency and Renewable Energy, Office of Transportation Technologies, Electric and Hybrid Propulsion Division.

\section{REFERENCES}

1. J. R. Dahn, A. K. Sleigh, H. Shi, J. N. Reimers, Q. Zhong and B. M. Way, Electrochimica Acta 38, p. 1179 (1993).

2. A. Omaru, H. Azuma, M. Aoki, A. Kita and Y. Nishi, 184th Electrochemical Society Meeting Extended Abstract, p. 34, Toronto, Canada, October, 11-16 (1992).

3. K. Sato, M. Noguchi, A. Demachi, N. Oki and M. Endo, Science 264, p. 556 (1994).

4. T. Iijima, K. Suzuki and Y. Matsuda, Denki Kagaku 61(12), p. 1383 (1993).

5. T. D. Tran, J. Feikert, X. Song and K. Kinoshita, J. Electrochem. Soc. 142, p. 3297 (1995).

6. K. Tatsumi, K. Zaghib, H. Abe, T. Ohsaki and Y. Sawada, Seventh International Meeting on Lithium Batteries, p. 249, Boston, MA, May 15-20 (1994).

7. R. Fong, U. von Sacken and J. R. Dahn, J. Electrochem. Soc. 137, p. 2009 (1990). 

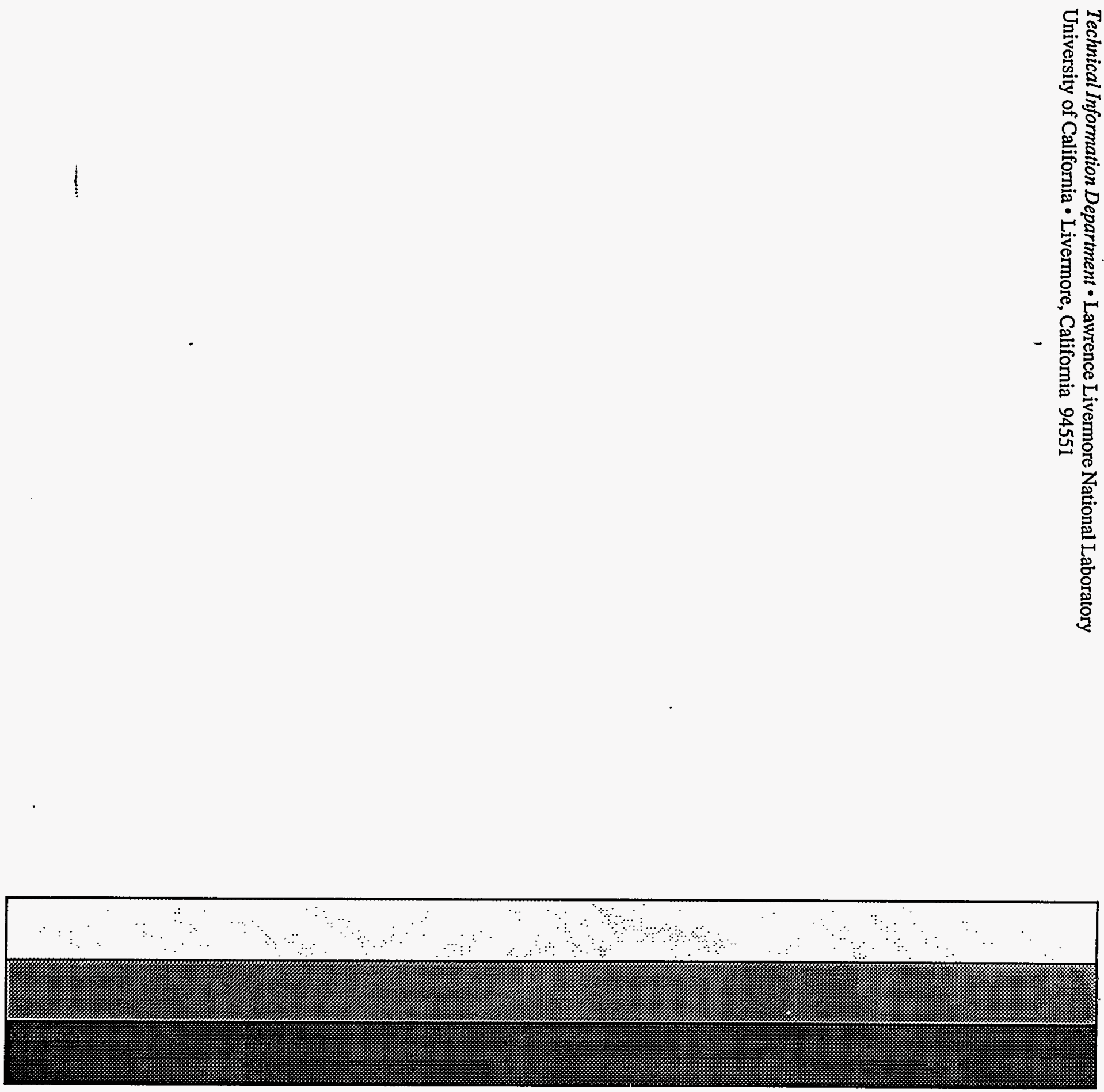